\title{
The relations of basic and dark personality traits with prosocial tendencies: Exploring gender differences
}

\author{
Anja Wertag ${ }^{1}$ \\ Institute of Social Sciences Ivo Pilar, Zagreb
}

Maja Ribar

Biometrika d.o.o., Zagreb

\section{Denis Bratko}

Department of Psychology, Faculty of Social Sciences and Humanities, University of Zagreb

Prosocial behaviour covers a broad range of actions that are intended to benefit others rather than oneself, thus forming different types of prosocial tendencies which are linked to different individual characteristics. Moreover, there are some gender differences in the types of prosocial behaviour that males and females engage in. Therefore, the aim of this study was to investigate personality traits associated with different forms of prosocial tendencies, as well as whether there were gender differences in these relations. Data were collected on-line on a total of 905 participants $\left(81 \%\right.$ female; $\left.M_{\text {age }}=24.30, S D=6.52\right)$, using the Prosocial Tendencies Measure (assessing 6 types of prosocial tendencies: altruistic, compliant, emotional, dire, public, and anonymous), the Ten Item Personality Inventory, and the Short Dark Triad. The results of hierarchical regression analyses (with basic personality traits entered in the first and dark personality traits in the second step) indicated that, although the percentage of explained variance in all types of prosocial tendencies was modest (up to the total of $24 \%$ ), basic personality traits contributed more to an explanation of public prosocial tendencies in males than in females. The dark traits had a (negative) contribution to the explanation of altruistic prosocial tendencies in both males and females, and a contribution above the basic traits in an explanation of emotional, dire and compliant prosocial tendencies only in females. Generally, the results showed some interesting patterns, highlighting gender differences in the relations of personality traits and prosocial tendencies.

Key words: prosocial tendencies, basic personality traits, the Dark Triad, gender differences

$1 \quad$ Anja.Wertag@pilar.hr 


\section{Introduction}

Prosocial behaviour is voluntary behaviour performed with the intention to benefit another (Eisenberg, Fabes, \& Spinrad, 2006). It covers actions such as cooperating, sharing, giving, helping, and comforting others (Batson \& Powell, 2003). These actions can be motivated by altruistic reasons, but there are also some egoistic reasons for prosocial behaviour, such as to receive praise or attention, to reduce uncomfortable feelings such as guilt, or to receive something in return (Batson, 2011). In line with this, as well as with theory and their research, Carlo and Randall (2002) identified four types of prosocial behaviour: altruistic prosocial behaviour (defined as voluntary helping motivated primarily by the concern for needs and welfare of others), compliant prosocial behaviour (defined as helping others in response to a verbal or nonverbal request), emotional prosocial behaviour (conceptualized as helping others under emotionally evocative circumstances) and public prosocial behaviour (performed in front of an audience, motivated at least in part by a desire to gain the approval and respect of others, and enhance one's self-esteem). Since some of the subscales in their pilot studies loaded on two distinct factors, Carlo and Randall (2002) also added anonymous (defined as helping performed without others being aware of who had helped them) and dire (helping in crisis or emergency situations) prosocial behaviour, which were derived from public prosocial behaviour and emotional prosocial behaviour, respectively. Due to the differences between these types of behaviour and the underlying motivation, it is not surprising that different types of prosocial behaviour are related to different personality traits (Rodrigues, Ulrich, Mussel, Carlo, \& Hewig, 2017). Within the Big Five space, traits that may be linked to prosocial behaviour are Extraversion (as extraverts might be more willing to perform thoughtless acts that may be linked to heroic prosocial behaviour) and Neuroticism (since high anxiety and vigilance to threat can undermine helping). However, Agreeableness generally emerges as the single best predictor of prosocial tendencies and behaviour, although it is not a universal predictor of all forms of prosocial tendencies (Graziano \& Habashi, 2015).

Recently, apart from linking prosocial behaviour to basic personality traits, a growing body of research has been devoted to investigating the relationship between prosocial behaviour and the Dark Triad traits. The Dark Triad constitutes of three socially aversive traits: Machiavellianism (characterized by a cynical world view and tendency towards manipulation), psychopathy (characterized by callousness and impulsivity), and narcissism (characterized by grandiosity, egocentrism and a sense of entitlement) (Paulhus \& Williams, 2002). Apart from showing consistent negative relations with Agreeableness, these traits are linked to maladaptive and antisocial tactics (Muris, Merckelbach, Otgaar \& Meijer, 2017). Moreover, the Dark Triad traits are located within the Quadrant II of the Wiggins's (1979) interpersonal circumplex model, which resembles high agency (i.e. striving for autonomy and superiority) and low communion (i.e. connecting with and helping others) (Jones \& Paulhus, 2011). 
Hence, it is not surprising that these traits are generally linked to being less likely to engage in helping behaviour (e.g. Bereczkei, Birkas, \& Kerekes, 2010; Lannin, Guyll, Krizan, Madon, \& Cornish, 2014; White, 2014). However, these traits seem to be positively linked to at least some forms of prosocial behaviour, such as self-reported (Kauten \& Barry, 2016; Zuo, Wang, Xu, Wang, \& Zhao, 2016), public (Konrath, Ho, Zarins, 2016; White, 2014) and opportunistic prosocial behaviour (Eberly-Lewis \& Coetzee, 2015), reflecting the nature of these traits. For example, it is possible that beneath the positive link between prosocial behaviour and narcissism, which is perceived as "brighter" than the other two dark traits (Rauthmann \& Kolar 2012), there lies a need for gaining social validation and rewards (Kauten \& Barry, 2014; Zuo et al., 2016).

There is a long history of theoretical articles and summaries of empirical research on gender differences in prosocial behaviour (e.g. Frieze \& Li, 2010). As Eagly (2009) summarizes, gender roles are a useful tool for understanding gender differences in prosocial behaviour. Namely, in line with common beliefs about gender roles, prosocial behaviour in women has a more communal focus (i.e. emotionally supportive and sensitive, especially in close relationships), while prosocial behaviour in men has a more agentic focus (heroic; often directed towards strangers and the support of social collectives), and both the empirical research (e.g. Espinosa \& Kováŕík, 2015) and official statistics (see Eagly, 2009) support this.

Apart from gender differences in prosocial behaviour, there are also gender differences in the Dark Triad traits, with men consistently scoring higher (e.g. Jonason, Li, Webster, \& Schmitt, 2009; Jones \& Weiser, 2014). Moreover, although some authors (e.g. Muris et al., 2017) point out that there are both empirical and theoretical reasons to assume that the dark traits and their correlates manifest themselves differently in males and females and that this should be taken into account, the research on gender differences in the relationship between prosocial tendencies and both the basic and dark personality traits is still scarce. Therefore, the aim of this study was to investigate personality traits associated with different forms of prosocial tendencies, as well as whether there were gender differences in these relations. Our hypothesis is that, among basic traits, Agreeableness will be the most consistent predictor of prosocial tendencies (in line with Graziano \& Habashi, 2015), and that higher Agreeableness will be linked to more pronounced prosocial tendencies. Moreover, we hypothesize that the Dark Triad traits will be negatively linked to some forms of prosocial behaviour, such as altruistic, and positively to some other forms, such as public prosocial behaviour (e.g. Bereczkei et al., 2010; White, 2014; Konrath et al., 2016). Finally, in line with the proposed gender roles explanation of gender differences in prosocial behaviour (Eagly, 2009), we hypothesize that there will be gender differences in the relations between personality traits and prosocial tendencies which will be in accordance with gender roles (i.e. prosocial tendencies in females will be more communal and positively related to Agreeableness, while in males they will be more agentic and positively related to Extraversion). 


\section{Method}

\section{Participants}

Participants were the students of the Faculty of Humanities and Social Sciences, University of Zagreb, Croatia. All the students whose e-mail address was on the Faculty's IT department mailing list received an e-mail invitation to participate in a larger study. A total of 905 students participated in this research $\left(M_{\text {age }}=24.30, S D=6.52\right)$, with 734 of them being female $\left(M_{\text {age }}=\right.$ $24.39, S D=6.67)$, and 171 of them male $\left(M_{\text {age }}=23.93, S D=5.82\right)$.

\section{Measures}

Prosocial tendencies. Prosocial behaviour was measured using the Prosocial Tendencies Measure (Carlo \& Randall, 2002). It assesses 6 types of prosocial tendencies: altruistic $(\alpha=.56)$, compliant $(\alpha=.81)$, emotional $(\alpha=$ $.84)$, dire $(\alpha=.73)$, public $(\alpha=.75)$, and anonymous $(\alpha=.84)$. Participants were asked to rate the extent to which each item described them on a 5-point scale $(1=$ does not describe me at all and $5=$ describes me greatly).

Big Five. The Big Five personality dimensions were measured using the Ten Item Personality Inventory (TIPI; Gosling, Rentfrow, \& Swann, 2003), where each dimension is operationalized with two pairs of traits. Participants were asked to rate the extent to which each pair of traits applied to them on a 7 -point scale $(1=$ disagree strongly and $7=$ agree strongly $)$. The Cronbach alpha reliabilities for Extraversion, Agreeableness, Consciousness, Emotional Stability, and Openness to Experience were .69, .35, .70, .70, and .43, respectively. Although reliabilities for Agreeableness and Openness were low, it should be taken into account that each trait was measured by only two items in which the emphasis was on content validity, and reliabilities were comparable to those from the original validation study (Gosling et al., 2003).

Both the Prosocial Tendencies Measure and TIPI were translated into Croatian by two independent translators. After reaching the consensus on all items, they were translated back to English. Several minor inconsistencies were amended through a discussion between the translators and the back-translator.

Dark Triad. The Dark Triad personality traits were measured using the Short Dark Triad (SD3; Jones \& Paulhus, 2014; for the Croatian version see Wertag, Vrselja, \& Tomić, 2011). Participants were asked to rate their agreement with each item on a 5 -point scale $(1=$ strongly disagree and $5=$ strongly agree $)$. Cronbach's alpha for Machiavellianism was .76, for narcissism .69 and for psychopathy .72.

\section{Procedure}

Data collection was carried out on-line. An invitation to participate was sent via e-mail by the Faculty's IT department to all students of the Faculty of Humanities and Social Sciences, University of Zagreb. Participation was 
completely anonymous and voluntary, with the invitation containing a short description of the research, and a link to an on-line platform where participants filled out the questionnaires.

\section{Data analysis}

The relationship between prosocial tendencies and personality traits was investigated through zero-order correlations and through coefficients in multiple regression analyses. In order to examine the contribution of basic and dark personality traits to the prediction of each prosocial behaviour, hierarchical multiple regressions were performed, with basic personality traits entered at the first, and dark personality traits entered at the second step of the analysis. All regression coefficients, including the squared multiple correlations and increments in squared multiple correlations (i.e., $\Delta R^{2}$ ), were given with $95 \%$ confidence intervals. Bootstrap confidence intervals were used since it has been shown that for the confidence interval of increase in the squared multiple correlation, the bootstrap approach performs better than the asymptotic one when this increase is small or when the sample size is relatively small (Algina, Keselman, \& Penfield, 2007; Algina, Keselman, \& Penfield, 2008). The number of samples used to create bootstrap confidence intervals was set to 1000 in all instances, and they were computed as suggested by Algina et al. (2007; 2008). Analyses were conducted separately for each gender, and gender differences were inferred from the nonoverlapping confidence intervals. This procedure was employed since it allows a comparison of not only the regression slopes for each gender (as do the analyses of interactions between gender and personality traits), but also of variance explained by each set of traits. Although non-overlapping confidence intervals imply a statistically significant difference between the groups, this method is considered conservative in the cases when there is an overlap between confidence intervals for the two groups (e.g. Schenker $\&$ Gentleman, 2001). The conservative approach was considered appropriate since there was a large number of confidence interval comparisons.

\section{Results}

Means, standard deviations, and correlations between prosocial behaviour, and basic and dark personality traits are shown in Table 1. Public prosocial behaviour had a larger positive correlation with Extraversion in the male than in the female sample, while it was negatively correlated with all the dark traits in both samples. Emotional and compliant prosocial behaviour had higher negative correlations with dark traits in the female sample, while altruistic prosocial behaviour had higher negative correlations with dark traits in the male sample. Compliant prosocial behaviour had larger positive correlations with basic personality traits in the female sample, while anonymous prosocial behaviour had relatively small correlations with personality in both samples. 


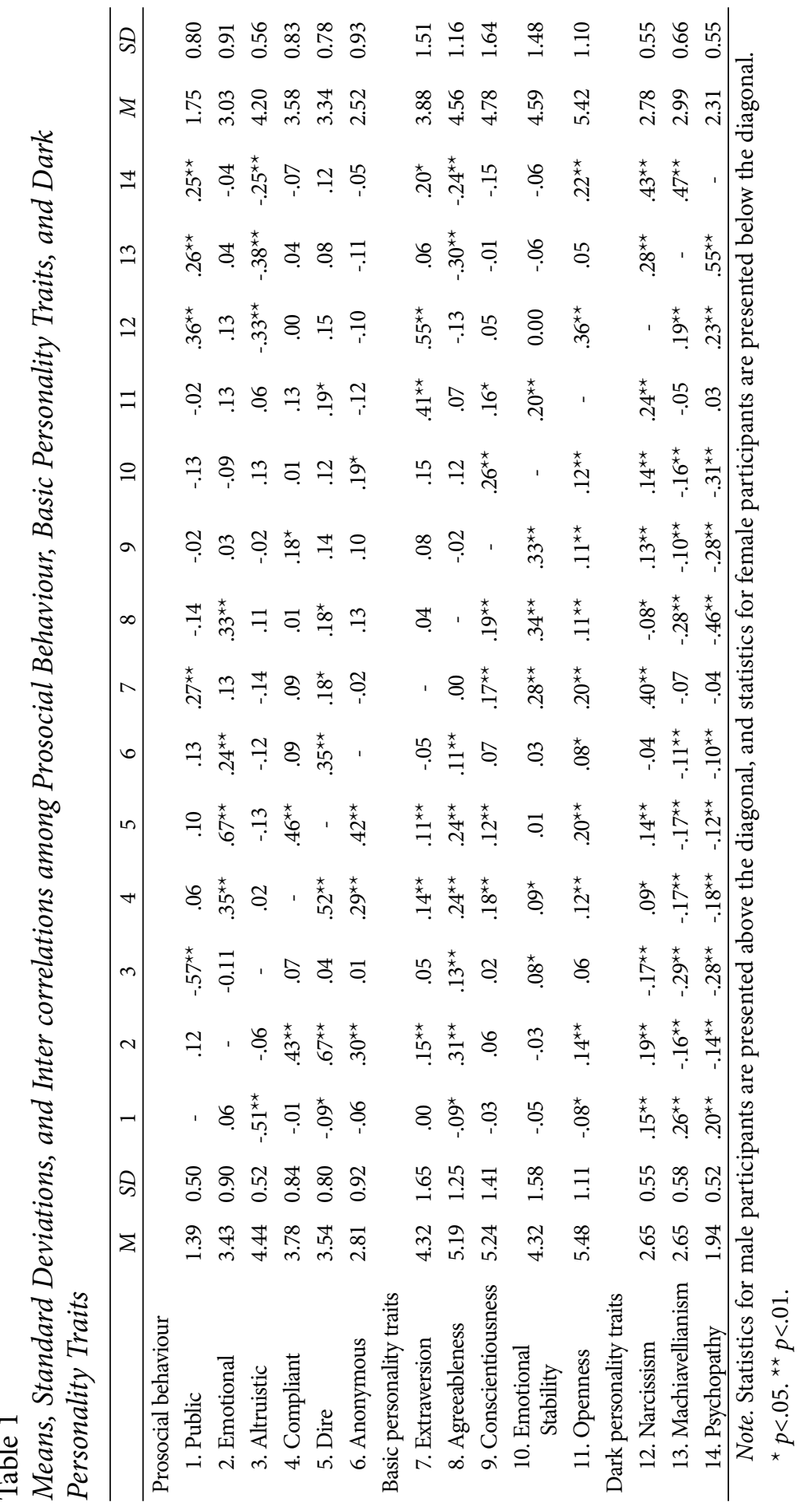


The prediction of public prosocial behaviour by basic and dark personality traits is shown in Table 2 . In females, basic personality traits explained only $1 \%$ of this form of prosocial behaviour, while in males the basic traits explained $12 \%$, and this difference was statistically significant. The addition of dark traits significantly improved prediction in both genders, with a fairly equal amount of additional variance explained. Although the amount of variance of public prosocial behaviour explained by basic and dark personality traits was larger in males compared to females, there was a slight overlap between the confidence intervals of multiple correlation coefficients, so this difference could not be reliably generalized to the population level.

At the trait level, none of the traits yielded a statistically significant gender difference, although there was only a small confidence interval overlap for Extraversion, with higher Extraversion being more correlated with public prosocial behaviour in males than in females. In both samples, more open individuals were less prone to public prosocial behaviour, while those with a higher level of narcissism were more likely to exhibit this type of prosocial behaviour.

Table 2

Hierarchical Regression Analysis Predicting Public Prosocial Behaviour with Basic and Dark Personality Traits for each gender

\begin{tabular}{|c|c|c|c|c|c|c|}
\hline \multirow[b]{2}{*}{ Step and predictor variable } & \multicolumn{3}{|c|}{ Females } & \multicolumn{3}{|c|}{ Males } \\
\hline & $\underline{B}$ & $95 \% \mathrm{CI}$ & $\beta$ & $\underline{B}$ & $95 \% \mathrm{CI}$ & $\beta$ \\
\hline \multicolumn{7}{|l|}{ Step 1} \\
\hline Extraversion & 0.00 & {$[-0.03,0.02]$} & -0.01 & 0.11 & {$[0.01,0.21]$} & $0.21^{\star}$ \\
\hline Agreeableness & 0.01 & {$[-0.02,0.04]$} & 0.03 & -0.01 & {$[-0.12,0.10]$} & -0.02 \\
\hline Conscientiousness & 0.00 & {$[-0.02,0.03]$} & 0.01 & 0.01 & {$[-0.07,0.09]$} & 0.02 \\
\hline Emotional Stability & -0.01 & {$[-0.03,0.02]$} & -0.02 & -0.05 & {$[-0.14,0.03]$} & -0.09 \\
\hline Openness to Experience & -0.04 & {$[-0.08,-0.01]$} & $-0.09^{\star}$ & -0.14 & {$[-0.25,-0.03]$} & $-0.19^{\star}$ \\
\hline \multicolumn{7}{|l|}{ Step 2} \\
\hline Narcissism & 0.11 & {$[0.03,0.19]$} & $0.12^{\star *}$ & 0.35 & {$[0.10,0.62]$} & $0.24^{*}$ \\
\hline Machiavellianism & 0.18 & {$[0.10,0.25]$} & $0.20^{\star *}$ & 0.18 & {$[-0.04,0.42]$} & 0.15 \\
\hline Psychopathy & 0.07 & {$[-0.02,0.16]$} & 0.07 & 0.10 & {$[-0.19,0.39]$} & 0.07 \\
\hline Step $1 R^{2}$ & .01 & {$[.00, .04]$} & & $.12^{\star *}$ & {$[.06, .24]$} & \\
\hline$\Delta R^{2}$ & $.08^{\star *}$ & {$[.04, .13]$} & & $.09^{* *}$ & {$[.04, .19]$} & \\
\hline Total $R^{2}$ & $.09^{\star *}$ & {$[.06, .15]$} & & $.22^{\star *}$ & {$[.14, .38]$} & \\
\hline $\mathrm{n}$ & & 686 & & & 161 & \\
\hline
\end{tabular}

Note. CI = bootstrap confidence interval based on 1000 samples. Regression coefficients with the non-overlapping confidence intervals between females and males are shown in boldface.

${ }^{\star} p<.05 .{ }^{* *} p<.01$.

The majority of emotional prosocial behaviour variance was explained by basic personality traits in both genders, with dark traits explaining a small additional amount of this behaviour variance (Table 3). More agreeable individuals of both genders were more prone to this type of prosocial behaviour. Although there was a gender difference in the direction of the relationship between Machiavellianism and emotional prosocial behaviour (with the relationship being negative for females, but positive for males), there was also a slight overlap in confidence intervals for this trait's regression coefficients. 
Table 3

Hierarchical Regression Analysis Predicting Emotional Prosocial Behaviour with Basic and Dark Personality Traits for each gender

\begin{tabular}{lcccccccc}
\hline & \multicolumn{4}{c}{ Females } & & \multicolumn{4}{c}{ Males } \\
\cline { 2 - 3 } Step and predictor variable & $B$ & $95 \% \mathrm{CI}$ & $\beta$ & & $95 \% \mathrm{CI}$ & $\beta$ \\
\hline Step 1 & & & & & & & \\
$\quad$ Extraversion & 0.05 & {$[0.01,0.10]$} & $0.10^{*}$ & & 0.03 & {$[-0.09,0.15]$} & 0.04 \\
$\quad$ Agreeableness & 0.28 & {$[0.22,0.34]$} & $0.39^{* *}$ & & 0.29 & {$[0.17,0.40]$} & $0.37^{* *}$ \\
$\quad$ Conscientiousness & 0.00 & {$[-0.05,0.05]$} & 0.00 & & 0.03 & {$[-0.06,0.12]$} & 0.05 \\
$\quad$ Emotional Stability & -0.16 & {$[-0.20,-0.11]$} & $-0.27^{* *}$ & -0.09 & {$[-0.21,0.01]$} & -0.15 \\
$\quad$ Openness to Experience & 0.05 & {$[-0.00,0.11]$} & 0.06 & & 0.04 & {$[-0.09,0.18]$} & 0.05 \\
Step 2 & & & & & & \\
$\quad$ Narcissism & 0.39 & {$[0.24,0.52]$} & $0.24^{* *}$ & 0.23 & {$[-0.07,0.53]$} & 0.14 \\
$\quad$ Machiavellianism & -0.16 & {$[-0.30,-0.02]$} & $-0.10^{*}$ & & 0.19 & {$[-0.03,0.43]$} & 0.14 \\
$\quad$ Psychopathy & -0.09 & {$[-0.26,0.07]$} & -0.05 & & -0.16 & {$[-0.47,0.16]$} & -0.10 \\
Step 1 $R^{2}$ & $.18^{* *}$ & {$[.13, .25]$} & & $.15^{* *}$ & {$[.08, .28]$} & \\
$\Delta R^{2}$ & $.05^{* *}$ & {$[.02, .09]$} & & .03 & {$[.00, .11]$} & \\
Total $R^{2}$ & $.23^{* *}$ & {$[.18, .30]$} & & $.18^{* *}$ & {$[.11, .34]$} & \\
$\mathrm{n}$ & & & 678 & & & 160 & \\
\hline
\end{tabular}

Note. $\mathrm{CI}=$ bootstrap confidence interval based on 1000 samples.

${ }^{\star} p<.05 .{ }^{* *} p<.01$.

In contrast to emotional prosocial behaviour, the majority of altruistic prosocial behaviour variance was explained by dark traits in both genders (Table 4). Total variance of altruistic prosocial behaviour explained by both groups of personality traits was to some degree larger in males than in females. Both females and males who scored higher on narcissism and Machiavellianism reported a lower level of altruistic behaviour.

Table 4

Hierarchical Regression Analysis Predicting Altruistic Prosocial Behaviour with Basic and Dark Personality Traits for each gender

\begin{tabular}{|c|c|c|c|c|c|c|}
\hline \multirow[b]{2}{*}{ Step and predictor variable } & \multicolumn{3}{|c|}{ Females } & \multicolumn{3}{|c|}{ Males } \\
\hline & $B$ & $95 \% \mathrm{CI}$ & $\beta$ & $B$ & $95 \% \mathrm{CI}$ & $\beta$ \\
\hline \multicolumn{7}{|l|}{ Step 1} \\
\hline Extraversion & 0.02 & {$[-0.00,0.04]$} & 0.07 & -0.00 & {$[-0.06,0.06]$} & -0.00 \\
\hline Agreeableness & -0.01 & {$[-0.05,0.03]$} & -0.03 & -0.02 & {$[-0.09,0.05]$} & -0.04 \\
\hline Conscientiousness & -0.02 & {$[-0.04,0.01]$} & -0.05 & -0.01 & {$[-0.06,0.03]$} & -0.04 \\
\hline Emotional Stability & 0.01 & {$[-0.02,0.04]$} & 0.04 & 0.04 & {$[-0.02,0.10]$} & 0.10 \\
\hline Openness to Experience & 0.04 & {$[0.01,0.07]$} & $0.08^{\star}$ & 0.07 & {$[-0.01,0.16]$} & 0.15 \\
\hline \multicolumn{7}{|l|}{ Step 2} \\
\hline Narcissism & -0.14 & {$[-0.22,-0.07]$} & $-0.15^{\star *}$ & -0.30 & {$[-0.47,-0.13]$} & $-0.30^{\star *}$ \\
\hline Machiavellianism & -0.16 & {$[-0.24,-0.08]$} & $-0.18^{\star \star}$ & -0.25 & {$[-0.39,-0.11]$} & $-0.31^{\star \star}$ \\
\hline Psychopathy & -0.15 & {$[-0.24,-0.06]$} & $-0.15^{\star \star}$ & -0.02 & {$[-0.21,0.16]$} & -0.02 \\
\hline Step $1 R^{2}$ & $.02^{*}$ & {$[.01, .06]$} & & .05 & {$[.00, .16]$} & \\
\hline$\Delta R^{2}$ & $.11^{\star *}$ & {$[.06, .16]$} & & $.18^{\star *}$ & {$[.10, .31]$} & \\
\hline Total $R^{2}$ & .13 & {$[.09, .20]$} & & $.24^{\star *}$ & {$[.17, .39]$} & \\
\hline $\mathrm{n}$ & & 671 & & & 156 & \\
\hline
\end{tabular}

Note. $\mathrm{CI}=$ bootstrap confidence interval based on 1000 samples.

${ }^{\star} p<.05 .{ }^{\star *} p<.01$.

Table 5 shows a prediction of compliant prosocial behaviour based on the basic and dark personality traits. When it comes to this type of prosocial behaviour, the proportion of variance explained by the examined personality 
traits was not statistically significant in males, and in females variance was mostly explained by basic traits. More conscientious individuals of both genders were more prone to compliant prosocial behaviour.

Table 5

Hierarchical Regression Analysis Predicting Compliant Prosocial Behaviour with Basic and Dark Personality Traits for each gender

\begin{tabular}{|c|c|c|c|c|c|c|}
\hline \multirow[b]{2}{*}{ Step and predictor variable } & \multicolumn{3}{|c|}{ Females } & \multicolumn{3}{|c|}{ Males } \\
\hline & $B$ & $95 \% \mathrm{CI}$ & $\beta$ & & $95 \% \mathrm{CI}$ & $\beta$ \\
\hline \multicolumn{7}{|l|}{ Step 1} \\
\hline Extraversion & 0.05 & {$[0.00,0.09]$} & $0.09^{*}$ & 0.05 & {$[-0.06,0.18]$} & 0.10 \\
\hline Agreeableness & 0.15 & {$[0.09,0.21]$} & $0.22^{\star *}$ & -0.01 & {$[-0.14,0.13]$} & -0.01 \\
\hline Conscientiousness & 0.06 & {$[0.02,0.11]$} & $0.11^{\star *}$ & 0.09 & {$[-0.00,0.18]$} & $0.18^{\star}$ \\
\hline Emotional Stability & -0.06 & {$[-0.10,-0.01]$} & $-0.11^{*}$ & -0.04 & {$[-0.14,0.06]$} & -0.07 \\
\hline Openness to Experience & 0.06 & {$[-0.00,0.11]$} & 0.07 & 0.10 & {$[-0.07,0.27]$} & 0.13 \\
\hline \multicolumn{7}{|l|}{ Step 2} \\
\hline Narcissism & 0.13 & {$[-0.01,0.27]$} & 0.08 & -0.15 & {$[-0.46,0.17]$} & -0.10 \\
\hline Machiavellianism & -0.13 & {$[-0.27,-0.02]$} & $-0.09^{*}$ & 0.11 & {$[-0.15,0.34]$} & 0.09 \\
\hline Psychopathy & -0.07 & {$[-0.24,0.10]$} & -0.04 & -0.12 & {$[-0.43,0.19]$} & -0.08 \\
\hline Step $1 R^{2}$ & $.10^{* *}$ & {$[.07, .16]$} & & .05 & {$[.00, .19]$} & \\
\hline$\Delta R^{2}$ & $.01^{\star}$ & {$[.00, .04]$} & & .01 & {$[.00, .10]$} & \\
\hline Total $R^{2}$ & $.12^{\star \star}$ & {$[.08, .18]$} & & .06 & {$[.00, .23]$} & \\
\hline $\mathrm{n}$ & & 686 & & & 157 & \\
\hline
\end{tabular}

When it comes to dire prosocial behaviour, dark personality traits explained a small amount of variance over and above the basic traits in both genders (Table 6). Agreeableness was positively related to this type of prosocial behaviour in both female and male participants. There was a small confidence interval overlap in the Emotional Stability regression coefficients, with lower emotional stability being correlated with dire prosocial behaviour in females but not in males.

Table 6

Hierarchical Regression Analysis Predicting Dire Prosocial Behaviour with Basic and Dark Personality Traits for each gender

\begin{tabular}{|c|c|c|c|c|c|c|}
\hline \multirow[b]{2}{*}{ Step and predictor variable } & \multicolumn{3}{|c|}{ Females } & \multicolumn{3}{|c|}{ Males } \\
\hline & $B$ & $95 \% \mathrm{CI}$ & $\beta$ & $B$ & $95 \% \mathrm{CI}$ & $\beta$ \\
\hline \multicolumn{7}{|l|}{ Step 1} \\
\hline Extraversion & 0.03 & {$[-0.01,0.07]$} & 0.05 & 0.02 & {$[-0.09,0.13]$} & 0.05 \\
\hline Agreeableness & 0.16 & {$[0.10,0.22]$} & $0.25^{\star *}$ & 0.13 & {$[0.02,0.25]$} & $0.21^{\star}$ \\
\hline Conscientiousness & 0.04 & {$[0.00,0.09]$} & $0.08^{\star}$ & 0.05 & {$[-0.02,0.13]$} & 0.11 \\
\hline Emotional Stability & -0.10 & {$[-0.14,-0.05]$} & $-0.19^{* *}$ & 0.03 & {$[-0.06,0.12]$} & 0.05 \\
\hline Openness to Experience & 0.10 & {$[0.05,0.15]$} & $0.14^{\star *}$ & 0.05 & {$[-0.08,0.19]$} & 0.07 \\
\hline \multicolumn{7}{|l|}{ Step 2} \\
\hline Narcissism & 0.21 & {$[0.07,0.35]$} & $0.15^{\star *}$ & 0.11 & {$[-0.18,0.40]$} & 0.08 \\
\hline Machiavellianism & -0.18 & {$[-0.29,-0.05]$} & $-0.13^{* *}$ & 0.08 & {$[-0.15,0.32]$} & 0.07 \\
\hline Psychopathy & -0.03 & {$[-0.18,0.12]$} & -0.02 & 0.12 & {$[-0.14,0.37]$} & 0.09 \\
\hline Step $1 R^{2}$ & $.12^{\star *}$ & {$[.08, .19]$} & & $.07^{\star}$ & {$[.03, .20]$} & \\
\hline$\Delta R^{2}$ & $.03^{\star *}$ & {$[.01, .06]$} & & .02 & {$[.00, .11]$} & \\
\hline Total $R^{2}$ & $.15^{\star \star}$ & {$[.11, .22]$} & & .10 & {$[.00, .26]$} & \\
\hline & & 687 & & & 159 & \\
\hline
\end{tabular}

Note. $\mathrm{CI}=$ bootstrap confidence interval based on 1000 samples.

${ }^{\star} p<.05 .{ }^{* *} p<.01$. 
The relationship of anonymous prosocial behaviour with basic and dark personality traits is shown in Table 7 , and the examined personality traits explained a small amount of this prosocial behaviour variance in both samples. However, there was a significant gender difference in the relationship between anonymous prosocial behaviour and Openness to Experience. While the more open females were more prone to this type of prosocial behaviour, in the male sample this relationship was in the opposite direction.

Table 7

Hierarchical Regression Analysis Predicting Anonymous Prosocial Behaviour with Basic and Dark Personality Traits for each gender

\begin{tabular}{|c|c|c|c|c|c|c|}
\hline \multirow[b]{2}{*}{ Step and predictor variable } & \multicolumn{3}{|c|}{ Females } & \multicolumn{3}{|c|}{ Males } \\
\hline & $B$ & $95 \% \mathrm{CI}$ & $\beta$ & $B$ & $95 \% \mathrm{CI}$ & $\beta$ \\
\hline \multicolumn{7}{|l|}{ Step 1} \\
\hline Extraversion & -0.04 & {$[-0.08,0.01]$} & -0.07 & -0.01 & {$[-0.13,0.12]$} & -0.02 \\
\hline Agreeableness & 0.05 & {$[-0.02,0.12]$} & 0.07 & 0.07 & {$[-0.06,0.21]$} & 0.09 \\
\hline Conscientiousness & 0.03 & {$[-0.03,0.09]$} & 0.05 & 0.04 & {$[-0.05,0.13]$} & 0.07 \\
\hline Emotional Stability & -0.01 & {$[-0.07,0.04]$} & -0.02 & 0.11 & {$[0.00,0.21]$} & $0.18^{\star}$ \\
\hline Openness to Experience & 0.08 & {$[0.02,0.15]$} & $0.10^{*}$ & -0.16 & {$[-0.32,-0.02]$} & $-0.19^{\star}$ \\
\hline \multicolumn{7}{|l|}{ Step 2} \\
\hline Narcissism & -0.05 & {$[-0.21,0.10]$} & -0.03 & -0.02 & {$[-0.33,0.28]$} & -0.01 \\
\hline Machiavellianism & -0.12 & {$[-0.27,0.03]$} & -0.08 & -0.14 & {$[-0.40,0.12]$} & -0.10 \\
\hline Psychopathy & -0.06 & {$[-0.23,0.12]$} & -0.03 & 0.12 & {$[-0.25,0.47]$} & 0.07 \\
\hline Step $1 R^{2}$ & $.03^{* *}$ & {$[.01, .07]$} & & $.07^{\star}$ & {$[.04, .20]$} & \\
\hline$\Delta R^{2}$ & .01 & {$[.00, .04]$} & & .01 & {$[.00, .09]$} & \\
\hline Total $R^{2}$ & $.04^{* *}$ & {$[.02, .09]$} & & .08 & {$[.00, .24]$} & \\
\hline $\mathrm{n}$ & & 676 & & & 158 & \\
\hline
\end{tabular}

Note. $\mathrm{CI}=$ bootstrap confidence interval based on 1000 samples. Regression coefficients with the non-overlapping confidence intervals between females and males are shown in boldface.

${ }^{\star} p<.05 .{ }^{* *} p<.01$.

\section{Discussion}

The main aim of this study was to investigate personality traits associated with different forms of prosocial tendencies, as well as whether there are gender differences in these relations. In line with previous findings (e.g. Rodrigues et al., 2017), our results showed that different basic personality traits were related to different prosocial tendencies. However, Agreeableness was the trait most consistently related to prosocial tendencies (i.e. emotional, dire and compliant in females, and emotional and dire in males), corroborating theoretical considerations and previous findings (see Graziano \& Habashi, 2015), followed by Openness to Experience, for which gender differences in relation to anonymous prosocial tendencies emerged.

\section{The effects of basic traits and gender differences}

Generally, basic personality traits predicted $18 \%$ and $15 \%$ of the variance of emotional prosocial tendencies, and $12 \%$ and $7 \%$ of dire prosocial 
tendencies in females and males, respectively. However, Emotional Stability was (negatively) related to emotional and dire prosocial tendencies only in females. Both of these prosocial tendencies are related to helping under the emotionally evocative situations or emergency situations, and it seems that the more emotionally reactive females tend to report helping more in such situations. Although Graziano and Habashi (2015) proposed that high anxiety might undermine helping, the other possible explanation is that the emotionally reactive females get more emotional and feel the relief in meeting the needs of others in highly emotional situations. Moreover, basic personality traits contributed to the prediction of the compliant (predicting $10 \%$ of the variance), and altruistic prosocial tendencies only in females (predicting $2 \%$ of the variance), and to the prediction of public prosocial tendencies (predicting 12\% of the variance) only in males, and the latter was a statistically significant gender difference in the relation between personality and prosocial tendencies in our study. More specifically, higher Extraversion was related to reporting more prosocial public behaviour only in males, which is in line with the proposal that extraverts might be more willing to perform the heroic prosocial acts (Graziano \& Habashi, 2015) that are often in the presence of others, and are more common for men (Eagly, 2009). In addition, lower Openness to Experience was linked to reporting more public prosocial behaviour, indicating that more conservative men tend to report helping more publicly, which is again in accordance with the male gender role and helping which is more agentic and directed towards strangers and the support of social collectives (Eagly, 2009). Finally, gender differences emerged in the prediction of anonymous prosocial tendencies, where Openness to Experience had a positive contribution in females and negative in males. In other words, it seems that more open-minded females and more conventional (and emotionally stable) males are more prone to anonymous prosocial behaviour.

\section{The effects of dark traits and gender differences}

Dark traits (negatively) predicted altruistic prosocial tendencies, explaining $11 \%$ and $18 \%$ of the variance in females and males, respectively. Interestingly, none of the basic traits (except Openness to Experience in females) had a significant contribution in predicting altruistic prosocial tendencies, and while in females all three dark traits contributed to the explanation of this form of prosocial behaviour, only Machiavellianism and narcissism contributed to the explanation of this form of prosocial behaviour in males. Moreover, dark traits had a significant contribution above the basic traits in the prediction of public prosocial tendencies in both males and females ( $9 \%$ and $8 \%$, respectively). However, only narcissism positively predicted this form of prosocial behaviour in males, while in females Machiavellianism also had a significant contribution, indicating that females high in these traits 
tend to report more engagement in public prosocial behaviour. Due to a gentic and selfish nature associated with the dark traits, the negative relation of the dark traits to altruistic prosocial tendencies and positive to public prosocial tendencies was both expected and in line with previous findings (e.g. Bereczkei et al., 2010; Eberly-Lewis \& Coetzee, 2015). Dark traits had a small, but significant (1-5\%) contribution above the basic traits in the prediction of emotional, dire and compliant prosocial behaviour in females. Given that these three prosocial tendencies were highly correlated, it is not surprising that a similar pattern with these three types of prosocial behaviour emerged: narcissism was positively related to them, while Machiavellianism was related negatively. A consistent positive relation of narcissism to most of the above-mentioned types of prosocial tendencies is in accordance with previous findings indicating a positive link between narcissism and the selfreported prosocial behaviour (Kauten \& Barry, 2016; Zuo et al., 2016). On the other hand, a negative link between Machiavellianism and emotional, dire and compliant prosocial behaviour might reflect a strategic orientation which is characteristic for Machiavellianism (see Jones \& Paulhus, 2011), in a way that females high on Machiavellianism strategically choose to remain calm and not react prosocially in emotional and dire situations in order to protect themselves, or simply have their own agenda and stick to it. Interestingly, although psychopathy was correlated with all forms of prosocial tendencies in females and altruistic and public prosocial tendencies in males, when the shared variance between the dark traits was controlled for, it did not contribute significantly to any form of prosocial tendencies (except altruistic in females). Finally, although previous research indicated the negative link of the dark traits and anonymous prosocial behaviour (e.g. White, 2014), the results of our study showed that only the basic traits predicted this type of prosocial behaviour.

\section{Limitations and future directions}

Although the results of the current study that investigated the gender differences in the relationship between different types of prosocial tendencies and both basic and dark traits are compelling, there are some limitations which need to be taken into account. First of all, our sample consisted of students, and the sample of male participants was relatively small. Moreover, the difference in the number of males and females implies that the statistical power in these subsamples was not the same, so the confidence intervals were also different, and much smaller for females. One of the clear consequences of the smaller sample of male participants is a higher number of statistically significant coefficients in the sample of female participants. Additionally, dark, and especially basic personality traits, were measured using short questionnaires. The reliabilities for Agreeableness and Openess to Experience 
were particularly low, but it should be borne in mind that in the construction of this questionnaire the emphasis was on (content) validity since only two items per trait were used and higher reliability would indicate a higher content overlap (Gosling et al., 2003). Given these circumstances, it is possible that our study did not have enough statistical power to detect additional gender differences that exist at the population level and that correlations would have been larger if we had measured basic personality traits with a larger and more reliable questionnaire. Finally, our study relied solely on the self-reported prosocial tendencies. Previous studies showed that self-reported prosocial behaviour is only one factor of prosociality, which is distinct from other forms of prosocial behaviour (Böckler, Tusche, \& Singer, 2016). Therefore, it would be good to replicate the findings of our study on a larger sample using full-length measures and other measures of prosocial behaviour apart from the self-report measure. There is also a possibility that the standard paperpencil method of data collection would yield somewhat different results.

\section{Conclusion}

This study showed that some types of prosocial tendencies are more linked to basic personality traits (such as emotional and dire prosocial tendencies), while some are more linked to dark personality traits (i.e. altruistic prosocial tendencies), emphasizing the importance of the Dark Triad in the personality space. Moreover, some interesting gender differences emerged: while anonymous prosocial tendencies were linked to higher Openness to Experience in females, the relationship was opposite in males. In addition, basic personality traits (Extraversion and Openness to Experience) predicted public prosocial tendencies only in males, and the dark traits had a significant contribution above and beyond the basic personality traits in predicting emotional, dire and compliant prosocial tendencies only in females. In sum, apart from highlighting the importance of both basic and dark traits in predicting prosocial tendencies, this study highlighted gender differences in the relations of personality traits and prosocial tendencies.

\section{References}

Algina, J., Keselman, H.J., \& Penfield, R.D. (2007). Confidence Intervals for an Effect Size Measure in Multiple Linear Regression. Educational and Psychological Measurement, 67(2), 207-218. doi:10.1177/0013164406292030

Algina, J., Keselman, H.J., \& Penfield, R.J. (2008). Note on a Confidence Interval for the Squared Semipartial Correlation Coefficient. Educational and Psychological Measurement, 68(5), 734-741. doi:10.1177/0013164407313371

Batson, C.D. (2011). Altruism in Humans. Oxford University Press (OUP). doi:10.1093/acprof:oso/9780195341065.001.0001 
Batson, C.D., \& Powell, A.A. (2003). Altruism and Prosocial Behavior. In T. Millon \& M. Lerner (Eds.), Handbook of Psychology. Personality and Social Psychology. Hoboken, NJ, USA: Wiley. Vol. 5. doi:10.1002/0471264385.wei0519

Bereczkei, T., Birkas, B., \&Kerekes, Z. (2010). The Presence of Others, Prosocial Traits, Machiavellianism. Social Psychology, 41(4), 238-245. doi:10.1027/18649335/a000032

Böckler, A., Tusche, A., \& Singer, T. (2016). The structure of human prosociality: Differentiating altruistically motivated, norm motivated, strategically motivated, and self-reported prosocial behavior. Social Psychological and Personality Science, 7(6), 530-541. doi:10.1177/1948550616639650

Carlo, G., \& Randall, B.A. (2002). The Development of a Measure of Prosocial Behaviors for Late Adolescents. Journal of Youth and Adolescence, 31(1), 31-44. doi:10.1023/a:1014033032440

Eagly, A.H. (2009). The his and hers of prosocial behavior: An examination of the social psychology of gender. American Psychologist, 64(8), 644-658. doi:10.1037/0003-066x.64.8.644

Eberly-Lewis, M.B., \& Coetzee, T.M. (2015). Dimensionality in adolescent prosocial tendencies: Individual differences in serving others versus serving the self. Personality and Individual Differences, 82, 1-6. doi:10.1016/j.paid.2015.02.032

Eisenberg, N., Fabes, R.A., \&Spinrad, T.L. (2007). Prosocial Development. In W. Damon \& R.M. Lerner (Eds.), Handbook of Child Psychology. Hoboken, NJ, USA: Wiley. doi:10.1002/9780470147658.chpsy0311

Espinosa, M.P., \& Kováŕík, J. (2015). Prosocial behavior and gender. Frontiers in Behavioral Neuroscience, 9, doi:10.3389/fnbeh.2015.00088

Frieze, I.H., \& Li, M.Y. (2010). Gender, Aggression, and Prosocial Behavior. In J.C. Chrisler \& D.R. McCreary (Eds.), Handbook of Gender Research in Psychology. (pp. 311-335). New York, NY: Springer Nature. doi:10.1007/978-1-4419-1467-5_13

Gosling, S.D., Rentfrow, P.J., \& Swann, W.B. (2003). A very brief measure of the BigFive personality domains. Journal of Research in Personality, 37(6), 504-528. doi:10.1016/s0092-6566(03)00046-1

Schroeder, D.A., Graziano, W.G., Graziano, W.G., \& Habashi, M.M. (2015). Searching for the Prosocial Personality. In D.A. Schroeder \& W.G. Graziano (Eds.), The Oxford Handbook of Prosocial Behavior. (pp. 231-255). Oxford, UK: Oxford University Press (OUP). doi:10.1093/oxfordhb/9780195399813.013.017

Jonason, P.K., Li, N.P., Webster, G.D., \& Schmitt, D.P. (2009). The dark triad: Facilitating a short-term mating strategy in men. European Journal of Personality, 23(1), 5-18. doi:10.1002/per.698

Jones, D.N., \& Paulhus, D.L. (2012). Differentiating the Dark Triad Within the Interpersonal Circumplex. In L.M. Horowitz \& S. Strack (Eds.), Handbook of interpersonal psychology: Theory, research, assessment, and therapeutic interventions. (pp. 249-267). Hoboken, NJ, USA: Wiley. doi:10.1002/9781118001868.ch15

Jones, D.N., \& Paulhus, D.L. (2014). Introducing the Short Dark Triad (SD3): a brief measure of dark personality traits. Assessment, 21(1), 28-41. doi:10.1177/1073191113514105

Jones, D.N., \& Weiser, D.A. (2014). Differential infidelity patterns among the Dark Triad. Personality and Individual Differences, 57, 20-24. doi:10.1016/j. paid.2013.09.007 
Kauten, R., \& Barry, C.T. (2014). Do you think I'm as kind as I do? The relation of adolescent narcissism with self- and peer-perceptions of prosocial and aggressive behavior. Personality and Individual Differences, 61-62, 69-73. doi:10.1016/j. paid.2014.01.014

Kauten, R.L., \& Barry, C.T. (2016). Adolescent narcissism and its association with different indices of prosocial behavior. Journal of Research in Personality, 60, 36-45. doi:10.1016/j.jrp.2015.11.004

Konrath, S., Ho, M., \& Zarins, S. (2016). The Strategic Helper: Narcissism and Prosocial Motives and Behaviors. Current Psychology, 35(2), 182-194. doi:10.1007/ s12144-016-9417-3

Lannin, D.G., Guyll, M., Krizan, Z., Madon, S., \& Cornish, M. (2014). When are grandiose and vulnerable narcissists least helpful. Personality and Individual Differences, 56, 127-132. doi:10.1016/j.paid.2013.08.035

Muris, P., Merckelbach, H., Otgaar, H., \& Meijer, E. (2017). The malevolent side of human nature: A meta-analysis and critical review of the literature on the Dark Triad (narcissism, Machiavellianism, and psychopathy). Perspectives on Psychological Science, 12(2), 183-204. doi:10.1177/1745691616666070

Paulhus, D.L., \& Williams, K.M. (2002). The Dark Triad of personality: Narcissism, Machiavellianism, and psychopathy. Journal of Research in Personality, 36(6), 556-563. doi:10.1016/s0092-6566(02)00505-6

Rauthmann, J.F., \& Kolar, G.P. (2012). How "dark", are the Dark Triad traits?, Examining the perceived darkness of narcissism, Machiavellianism, and psychopathy. Personality and Individual Differences, 53, 884-889. doi:https://doi. org/10.1016/j.paid.2012.06.020

Rodrigues, J., Ulrich, N., Mussel, P., Carlo, G., \& Hewig, J. (2017). Measuring prosocial tendencies in Germany: Sources of validity and reliability of the revised prosocial tendency measure. Frontiers in Psychology, 8, 2119-2125. doi:https:// doi.org/10.3389/fpsyg.2017.02119

Schenker, N., \& Gentleman, J.F. (2001). On Judging the Significance of Differences by Examining the Overlap Between Confidence Intervals. The American Statistician, 55(3), 182-186. doi:10.1198/000313001317097960

White, B.A. (2014). Who cares when nobody is watching? Psychopathic traits and empathy in prosocial behaviors. Personality and Individual Differences, 56, 116121. doi:10.1016/j.paid.2013.08.033

Wertag, A., Vrselja, I., \& Tomić, T. (2011). Assessing Construct Validity of Paulhus's and Williams's (2002) Dark Triad Questionnaire D3-27 / Provjera konstruktne valjanosti Paulhusovog i Williamsovog (2002) upitnika Mračne trijade D3-27. In: 19th Annual Conference of Croatian Psychologists. Osijek, Croatia.

Wiggins, J.S. (1979). A psychological taxonomy of trait-descriptive terms: The interpersonal domain. Journal of Personality and Social Psychology, 37(3), 395-412. doi:10.1037//0022-3514.37.3.395

Zuo, S., Wang, F., Xu, Y., Wang, F., \& Zhao, X. (2016). The fragile but bright facet in the Dark Gem: Narcissism positively predicts personal morality when individual's self-esteem is at low level. Personality and Individual Differences, 97, 272-276. doi:10.1016/j.paid.2016.03.076 


\section{Odnos temeljnih i mračnih crta ličnosti s prosocijalnim tendencijama: Ispitivanje rodnih razlika}

\section{Anja Wertag}

Institut društvenih znanosti Ivo Pilar

\section{Maja Ribar}

Biometrika d.o.o., Zagreb

\section{Denis Bratko}

Odsjek za psihologiju, Filozofski fakultet Sveučilišta u Zagrebu

Prosocijalno ponašanje se odnosi na širok spektar akcija usmjerenih na postizanje koristi za druge prije nego na postizanje vlastite koristi, formirajući različite tipove prosocijalnih tendencija, koje su povezane s različitim individualnim karakteristikama. Također, postoje spolne razlike u tipovima prosocijalnog ponašanja $u$ koje se žene i muškarci upuštaju. Stoga je cilj ovog istraživanja bio ispitati osobine ličnosti povezane s različitim oblicima prosocijalnih tendencija, te rodne razlike u ovim odnosima. Podaci su prikupljeni on-line na ukupno 905 sudionika (81\% ženskog spola; $M_{\mathrm{dob}}=24.30, S D=6.52$ ) putem Mjere prosocijalnih tendencija (Prosocial Tendencies Measure; koja obuhvaća 6 tipova prosocijalnih tendencija: altruistične, poslušne, emocionalne, hitne, javne i anonimne), Deset-čestičnog inventara ličnosti (Ten Item Personality Invenotry) i Kratkog upitnika Mračne trijade (Short Dark Triad). Rezultati hijerarhijske regresijske analize (s temeljnim crtama ličnosti u prvom koraku, te mračnim crtama u drugom) su pokazale da su, iako je postotak objašnjene varijance u svim tipovima prosocijalnih tendencija bio skroman (do ukupno 24\%), temeljne crte ličnosti više doprinijele objašnjenju javnih prosocijalnih tendencija kod muškaraca nego kod žena. Mračne crte su imale (negativan) doprinos objašnjenju altruističnih prosocijalnih tendencija $\mathrm{i}$ kod muškaraca i kod žena, te doprinos objašnjenju emocionalnih, hitnih i poslušnih prosocijalnih tendencija iznad temeljnih crta ličnosti samo kod žena. Općenito, rezultati su pokazali zanimljive obrasce, naglašavajući spolne razlike u odnosu crta ličnosti i prosocijalnih tendencija.

Ključne riječi: prosocijalne tendencije, temeljne crte ličnosti, Mračna trijada, spolne razlike 